\title{
Skin diseases affecting a population occupationally exposed to terrestrial fauna and flora in Brittany over a 15-year period
}

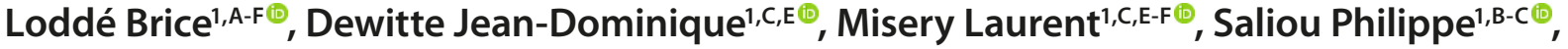 \\ Roguedas-Contios Anne-Marie ${ }^{1, A-B, E}{ }^{\infty}$, Maurel Damien-Thibaud ${ }^{1, B-D} \odot$ \\ ${ }^{1}$ Centre Hospitalier Régional (CHU) Morvan, France \\ A - Research concept and design, B - Collection and/or assembly of data, C - Data analysis and interpretation, \\ $D$ - Writing the article, E - Critical revision of the article, F - Final approval of article
}

Loddé B, Dewitte JD, Misery L, Saliou P, Roguedas-Contios AM, Maurel DT. Occupational skin diseases affecting a population occupationally exposed to Brittany's terrestrial fauna and flora over a 15-year period. Ann Agric Environ Med. 2020; 27(2): 211-218. doi: 10.26444/aaem/119142

\begin{abstract}
Introduction and objective. Brittany is the leading agricultural production region of France where many workers are exposed to the local flora and fauna. The aim of the study is to describe the different skin diseases found among the workers occupationally exposed to the terrestrial fauna and flora in Brittany, and to assess the possible over-representation of some work environments.

Materials and methods This was a retrospective, descriptive study carried out between 1 October 2002 - 30 April 2017 , based on the coding of files from a multi-disciplinary occupational dermatology clinic at the Brest University Hospital

Results. The study population of 84 patients was drawn from a total 788 patients seen during this period. Allergic contact dermatitis was the most frequently coded diagnosis with 35 cases $(42 \%)$. There were 13 cases of irritant contact dermatitis (15\%). Infectious diseases were poorly represented with only 5 cases (6\%).The 6 most frequently represented occupations were packers in the agri-food industry (12.0\%), cattle farmers and tomato greenhouse workers (both 10.7\%), maintenance workers of parks and gardens (9.5\%), agri-food factory cleaning operatives (8.3\%) and pig farmers (7.1\%).

Conclusions. There was a marked incidence of allergic contact dermatitis and irritative contact dermatitis, mostly occupational in origin. While no specific diseases were found among these workers, some of the allergens and irritants identified may be specific to certain work environments. Overall, there did not seem to be a major risk of occupational dermatoses among workers exposed to Brittany's terrestrial fauna and flora in this population, compared with other professional sectors, such as hairdressing or care work. The incidence rate of the cases of occupational skin diseases in this population is assessed from 3 - 5 cases per 100,000 workers.
\end{abstract}

\section{Key words}

dermatitis, occupational disease, environmental exposure, agriculture

\section{INTRODUCTION}

According to France's National Institute of Statistics and Economic Studies, Brittany is a region with a strong agricultural output compared with the French national average. Although it its inhabitants represents only $4.9 \%$ of the French population, the area produces $58 \%$ of the national pig meat tonnage, $43 \%$ of the nation's egg output, $33 \%$ of its poultry meat, $22 \%$ of its milk, and $21 \%$ of its veal. It ranks top nationally in terms of employment in the slaughtering and meat processing industry with 27,000 employees. Given the number of working Bretons registered at the Agricultural Social Security (MSA), the annual average population of agricultural workers (i.e. farm owners and their employees) is about 60,000 people.

Brittany is also a leading vegetable-producing region. In 2010 , more than 47,000 ha were used principally for vegetable growing, representing $20 \%$ of France's total vegetableproducing surface area. The region grows more than $90 \%$ of the national cauliflower tonnage, $78 \%$ of France's artichokes, $55 \%$ of its spinach, more than $50 \%$ of its shallots, $39 \%$ of

Address for correspondence: Loddé Brice, CHU Morvan, France

E-mail: bricelodde@yahoo.fr

Received: 30.06.2019; accepted: 17.03.2020; first published: 31.03.2020 its shell beans, $32 \%$ of its peas and green beans, $25 \%$ of its tomatoes and $25 \%$ of its cider apples.

Employment linked to agricultural activity in Brittany is almost twice the national average ( $4.5 \%$ vs. $2.5 \%)$. The industrial sector in the region is also larger than in the rest of France (13.7\% vs. 12.5\%), with the agri-food industries accounting for $40 \%$ of all industrial-sector jobs in Brittany, compared with $15 \%$ in mainland France.

Given the high prevalence of workers exposed to terrestrial flora and fauna in this region (approx. 100,000 people in Brittany), it seemed worthwhile to examine the dermatological nosology within this population by collecting data from multi-disciplinary occupational dermatology consultations. Despite the fact that the skin and mucous membranes are the body's primary interfaces with this specific environment, there appeared to be only isolated cases of many types of occupational dermatitis in Brittany.

From the medico-legal point of view, France's National Research and Safety Institute for the Prevention of Occupational Accidents and Diseases (INRS) defines an occupational disease as one that occurs as a direct consequence of a worker's exposure either to specific work demands, or to one or more harmful physical, chemical or biological substances. More specifically, occupational dermatoses are skin diseases resulting wholly or partially 
from an individual's working conditions [1]. It is estimated that they represent approximately $10 \%$ of general skin nosography, affecting $7-8$ employees in 10,000 a year in Europe [2]. In France, 1\% of workers suffer from occupational skin disease, representing 5\% of all occupational diseases leading to the compensation of affected workers. In addition, there are a large number of undiagnosed skin troubles, since it is estimated that occupational skin diseases account for approximately $40 \%$ of physical occupational symptoms $[3,4]$.

In order to respond to the specific investigation of this kind of diseases, the multi-disciplinary occupational dermatology clinic at Brest University Hospital (Centre Hospitalier Régional Universitaire de Brest) was set up in October 2002. This clinic takes place in the Occupational Diseases Department of Brest University Hospital where 700 - 1,000 patients come for consultations every year. In Brittany, a second Occupational Diseases Department welcomes patients in the University Hospital of Rennes which, however, does not have such a clinic. In the fifteen years since the inception of the Brest Occupational Dermatology Clinic until the end of April 2017, there seemed on the face of it to be a high prevalence of allergic diseases and a virtual absence of infectious diseases (Lyme disease, onyxis, mycosis, cutaneous tuberculosis, tularemia, pasteurellosis, etc.) in patients occupationally exposed to flora, or to food not yet packaged for distribution. However, no descriptive investigation had yet been conducted.

\section{OBJECTIVE}

The aim of the study is to examine the main occupational diagnoses made during occupational dermatology consultations at Brest University Hospital for a population occupationally exposed to the terrestrial fauna and flora in Brittany, and to compare the number of infectious diseases with the number of allergic diseases according to patients' occupations where these had exposed them to risk.

\section{MATERIALS AND METHOD}

This was a nosological study based on the coding of files from multi-disciplinary occupational dermatology consultations held exclusively at Brest University Hospital. At least one dermatologist and one occupational physician were present at the consultations.

The period of the study was 1 October $2002-30$ April 2017. All the files from this specific clinic had been uploaded onto the RNV3P (Réseau National de Vigilance et de Prévention des Pathologies Professionnelles) national network for the vigilance and prevention of occupational pathologies) during the study period. The study was therefore a descriptive, retrospective, socio-professional study of cases from a hospital-based occupational dermatology clinic. The uniqueness of this study lay in its focus on diseases diagnosed in patients with occupational exposure to Brittany' sterrestrial flora and fauna.

Population - Inclusion criteria. In order to meet the study's inclusion criteria, patients had to have had a professional activity that had exposed them several times a week over the space of at least one month in the previous year to one of the following working conditions:
- an immediate proximity to live animals;

- contact with fruit, vegetables or mushrooms not yet packaged for consumption;

- an immediate proximity over several hours to non-food flora.

The total annual number of this exposed population was approximately 100,000 people.

Exclusion criteria. In order to specifically target people exposed to Brittany's terrestrial flora and fauna, the exclusion criteria were as follows:

- a work environment exposing the individual to seafood products (e.g. fishing, shellfish farming, industry, etc.);

- a work environment exposing the individual to already cooked or prepared food (e.g. catering);

- a non-dermatological diagnosis;

- a place of work outside Brittany.

Groups. Five a priori groups were identified, based on anticipated production sectors in the Brittany region:

1) livestock farming for food production (cattle for meat or milk, pigs, poultry, etc.);

2) fruit and vegetable farming (tomatoes, artichokes, etc.);

3) non-food flora (horticulture, parks and gardens maintenance, etc.);

4) industrial packaging sector (agri-food packaging industry, cleaning company within these industries, butchers, etc.);

5) other (this group included patients who could not be classified into any of the previous groups due to insufficient detail in their files).

Only one type of exposure was retained per patient, namely that corresponding to their main professional activity. For example, the dairy farmers in Brittany very frequently had crop fields to feed their cattle, but in the current study they were classified into the 'livestock farming' group, even though, theoretically, they could also have been included in the 'non-food flora' group.

Parameters studied. The data extracted from the coding of each file were: gender, age at the time of consultation, work environment (coded according to ISCO-08: 2007 International Standard Classification of Occupations), main diagnosis established at the end of the consultation (coded according to the ICD-10, 10th revision of the International Classification of Diseases), link (or not) between the disease and occupational exposure and the harmful substance identified as the cause of the skin disease.

In cases where additional data was required in order to meet the objectives of this nosological survey, the occupational dermatology consultation files were examined. In most cases, however, the coding was sufficient to determine the diagnostic conclusion from the consultation and the patient's occupation.

Concerning the specific cases of contact dermatitis, the consultation doctors used the Mathias criteria [5] to guide them in diagnosing or not diagnosing an occupational allergic disease. In addition, the diagnosis of irritant contact dermatitis was based on the patient's anamnesis and the clinical appearance of the lesions. The main characteristics of irritant dermatitis were that it occurred in the majority of participants who had been exposed to irritants in their work 
environment, it was often collective in nature, appeared in the first few hours after contact, and was necessarily limited to the area of contact with the irritants. There had to be no extension of lesions away from the contact area, and patch tests had to be negative.

Allergic contact dermatitis, which is represented primarily by allergic contact eczema (more than allergic protein contact dermatitis), was diagnosed based on the patient's anamnesis, clinical appearance of the lesions, and the results of skin allergy tests.

In cases where an occupational allergic contact eczema was suspected, a standard European battery of skin tests was systematically carried out. These tests could also be supplemented with specific patch tests and/or patch tests using the products handled by the patients when other haptens were suspected of having potentially caused the dermatitis. Once these tests results had been received, the two senior doctors involved systematically discussed the relevance of any positive result.

Cases of occupational protein contact dermatitis were suspected when patients presented with chronic forms of eczema and/or rapid-onset lesions on their return to work (pruriginous erythematic lesions, urticarial papules, etc.). To investigate for this particular dermatitis, the doctors carried out:

- prick tests with commercially available solutions containing the suspected animal, vegetable and/or fruit allergens and, where appropriate, prick tests prepared with products brought into the clinic by the patients;

- where possible, specific IgE assays against the flesh and dander of the animals that the patients were in contact with (cattle, sheep, leporidae, etc.) and/or with the vegetables, fruits or plants in the patient's professional environment.

A positive result from either of these investigations, combined with a concordant clinical examination and anamnesis, led to the diagnosis of allergic protein contact dermatitis.

Method of analysis. The software used was as follows:

- Google Chrome ${ }^{\circledR}$ and Internet Explorer ${ }^{\circledR}$ web browsers;

- RNV3P (an online data entry and collection tool);

- Excel ${ }^{\circledR}$ spreadsheet and LibreOffice ${ }^{\circledR}$ (digital data processing software);

- Word ${ }^{\circledR}$ and LibreOffice ${ }^{\circledR}$ (word processing software).

For describing the study population, the qualitative variables were expressed in percentages. These variables were compared between the groups using a $\mathrm{CHI}^{2}$ test. The quantitative variables were expressed as medians and means. Potential comparisons between these groups were tested using an unpaired two-sample Student t-test. The alpha level (a) was set at $5 \%$.

\section{RESULTS}

Population. A total of 788 patients from all types of work were seen at the clinic in Brest during the period studied. Of these, 788,96 patients initially presented at least one of the inclusion criteria. Of these 96, 12 also presented at least 1 exclusion criterion: 3 were exposed to seafood products in their work environment (fishing, shellfish farming, etc.), 1 was exposed to already cooked foods in their work environment, and 8 were given a non-dermatological principal diagnosis at the end of the consultation (respiratory and ophthalmological diseases were the 2 types of diseases that prompted the patients to this specific consultation). A total of 84 patients were therefore included in the study population.

\section{PARAMETERS}

Gender - The study population was composed with 50 male patients (59.5\%) and 34 female patients (40.5\%). The gender ratio was therefore 1.47 .

Age - The minimum age at the time of consultation was 17 years; mean and median ages -39 years; maximum age -62 years.

Work environments - live animals. The group comprised 23 patients -9 in the beef sector, 6 in the pig sector, 3 in the poultry sector, 1 in rabbit husbandry, 1 seller of 'domestic animals' (no further details were available), and 3 'livestock farmers' (no other details were available in the medical file).

Fruit and vegetable farming. The group comprised 17 patients - 9 agricultural workers in tomato greenhouses, 2 seasonal workers in artichoke farming, 1 shiitake farmer, 1 cauliflower farmer, 1 worker in a parsley market garden, 1 strawberry greenhouse employee, 1 salaried maize farmer, 1 shallot and potato sorter.

Non-food flora. The group comprised 11 patients -8 parks and gardens maintenance workers, 2 horticulture workers and 1 apprentice florist.

Industrial packaging sector. Comprised 24 patients - 10 packers in agri-food processing plants, 7 cleaning operatives in agri-food processing plants, 5 meat cutters, 1 wooden pallet repairer, and 1 maintenance technician in the agrifood industry.

Another group comprised 9 patients but the information in their files prevented them being classifying into any of the above groups: 1 agricultural equipment driver, 1 farming cooperative employee, 1 stand-in farmer, 1 trainee farmer (professional baccalaureate), 5 'farmers' whose work environments and exposure to terrestrial flora and fauna were not specified. The largest groups represented were therefore industry (28.6\%) and animal husbandry (27.4\%).

The most common occupations were: packer in the agrifood industry (12.0\%), cattle farmer and tomato greenhouse worker (both 10.7\%), parks and gardens maintenance worker (9.5\%), agri-food factory cleaning operative (8.3\%) and finally pig farmer (7.1\%).

Occupational etiologies. At the end of the consultations it was decided that in 51 patients their skin diseases was occupational in origin ( $61 \%$ of the studied population). In this working population exposed to the fauna and flora in Brittany, the incidence rate of annual occupational skin diseases cases diagnosed at the Brest University Hospital Clinic could therefore be assessed as 3 - 5 cases per 100,000 workers. 
Nosology. Allergic contact dermatitis was the most frequently coded dermatitis with 35 cases (42\%). There were 13 cases (15\%) of irritant contact dermatitis. Infectious diseases were poorly represented with only 5 cases $(6 \%)$. There were 29 cases of other types of dermatitis (34.5\%).

Table 1. Number of patients by disease code, sorted by frequency of appearance

\begin{tabular}{|c|c|c|}
\hline Diseases (ICD-10) & $\begin{array}{l}\text { Total number } \\
\text { (n) and } \\
\text { percentage }\end{array}$ & $\begin{array}{c}\text { Concluded as } \\
\text { occupational } \\
\text { diseases (n) }\end{array}$ \\
\hline Allergic contact dermatitis (L23) & $35(41.7 \%)$ & 32 \\
\hline Irritant Contact Dermatitis (L24) & $15(17.9 \%)$ & 14 \\
\hline Infectious skin diseases: & $5(6.0 \%)$ & 1 \\
\hline B35 - Dermatophytosis & $1(1.2 \%)$ & 1 \\
\hline B33.8 - Other specified viral disease & $1(1.2 \%)$ & 0 \\
\hline B35.2 - Tinea manuum & $1(1.2 \%)$ & 0 \\
\hline B86 - Scabies & $1(1.2 \%)$ & 0 \\
\hline $\begin{array}{l}\text { L08 - Other local infection of skin and sub- } \\
\text { cutaneous tissue }\end{array}$ & $1(1.2 \%)$ & 0 \\
\hline Other skin diseases: & $29(34.5 \%)$ & 4 \\
\hline L20 - Atopic dermatitis & $6(7.1 \%)$ & 0 \\
\hline L40 - Psoriasis & $4(4.8 \%)$ & 0 \\
\hline L30 - Other dermatitis & $3(3.6 \%)$ & 0 \\
\hline L50 - Urticaria & $3(3.6 \%)$ & 1 \\
\hline R60 - Oedema, not elsewhere classified & $2(2.4 \%)$ & 1 \\
\hline L25 - Unspecified contact dermatitis & $2(2.4 \%)$ & 1 \\
\hline $\begin{array}{l}\text { L98.9 - Disorder of skin and subcutaneous tissue, } \\
\text { unspecified }\end{array}$ & $2(2.4 \%)$ & 1 \\
\hline L93.2 - Other local lupus erythematosus & $1(1.2 \%)$ & 0 \\
\hline $\begin{array}{l}\text { M32.8 - Other forms of systemic lupus } \\
\text { erythematosus }\end{array}$ & $1(1.2 \%)$ & 0 \\
\hline L70.0 - Acne vulgaris & $1(1.2 \%)$ & 0 \\
\hline C43.6 - Melanoma of upper limb & $1(1.2 \%)$ & 0 \\
\hline L90.5 - Scar conditions and fibrosis of skin & $1(1.2 \%)$ & 0 \\
\hline $\begin{array}{l}\text { L54.8 - Erythema in other diseases classified } \\
\text { elsewhere }\end{array}$ & $1(1.2 \%)$ & 0 \\
\hline $\begin{array}{l}\text { L85.1 - Acquired keratosis [keratoderma] palmaris } \\
\text { et plantaris }\end{array}$ & $1(1.2 \%)$ & 0 \\
\hline
\end{tabular}

Analysis according to disease - Focus on the 35 patients with allergic contact dermatitis.

The ICD-10 does not differentiate between allergic contact eczema and protein contact dermatitis, both of which are grouped under the code 'L23 allergic contact dermatitis'. Nevertheless, based on the data available in the files, it could be determined that 24 patients had allergic contact eczema and 11 had protein contact dermatitis.

\section{Details of the sensitizations and type of allergic contact dermatitis (Table 2).}

Gender - There were21 male patients (60\%) and 14 female patients (40\%). The gender ratio was therefore 1.5 .

Age - This subgroup comprised patients aged 17 - 61 years; median age - 38 years; mean age -39 years. There was no significant difference in the age of patients with allergic contact dermatitis compared with the other patients in the study $(\mathrm{p}>0.88)$
Occupational etiology. The majority of the allergic dermatitis cases were occupational in origin (32 of 35 cases - 91\%).

Work environments. The cattle farming (4 cases), pig farming ( 3 cases), tomato growing ( 3 cases) and cured-meat processing ( 3 cases) sectors were the most frequently represented among this group.

The cleaning and disinfecting sector was also frequently represented (one-third of cases), generally as a result of an allergy to the contents of disinfectant products. There were 4 cases of a glutar aldehyde allergy, and 2 of a benzalkonium chloride allergy.

The number of cases of allergies to the food (or plant) being produced was also high, albeit to a lesser extent -10 cases $(28 \%)$.

\section{Comparison of sensitizations according to production sectors.}

- Primary sector - included occupations linked to the exploitation of natural resources, of unprocessed raw materials (e.g. agri-culture).

- Secondary sector - included occupations linked to the processing of raw materials (e.g. agri-food industries).

- Primary sector workers - 23 patients were primarily sensitised (10 cases) to allergens from living organisms, and secondly (6 cases) to cleaning or disinfection products.

- Secondary sector workers - 12 patients, contrarily were primarily sensitised (7 cases) to cleaning or disinfection products, and secondly in 3 cases to allergens from living organisms.

Further details on protein contact dermatitis. In this group, the sector most affected by protein contact dermatitis was fruit and vegetable production (especially tomatoes), with organic allergens originating directly from production. The second most affected sector was meat production.

\section{Focus on the 15 patients with irritant contact dermatitis.}

Gender. There were 6 male patients (40\%) and 9 female patients $(60 \%)$. The gender ratio was therefore 1:5. There was no significant difference with the other patients in the study $(\mathrm{p}>0.11)$.

Age. This subgroup comprised patients aged 21 - 55 years; median age -34 years; mean age -36 years. There was no significant difference in the age of patients with irritant contact dermatitis compared with other patients in the study group ( $p>0.29)$.

Occupational etiology. The vast majority of the irritant dermatitis cases were occupational in origin (14 of 15 cases [93.3\%]).

Work environment. 5 cases were found in the live animals group, represented by 1 cattle farmer with no clear identification of the irritant, 2 pig farmers where the irritants were cleaning products and wet work, 1 poultry farmer where the irritant was a cleaning product, 1 'farmer' (with no details on the nature of her farming) the irritant was soap.

In the fruit and vegetable farming group, four cases were found: 3 tomato greenhouse workers where the irritants were insecticides and tomato plants, and 1 seasonal artichoke 
Table 2. Details of each patient with allergic contact dermatitis

\begin{tabular}{|c|c|c|c|c|c|}
\hline Type of work & $\begin{array}{l}\text { Age } \\
\text { (years } \\
\text { old) }\end{array}$ & $\begin{array}{l}\text { Sensitization (causative haptens or } \\
\text { allergens found) }\end{array}$ & $\begin{array}{l}\text { Type of allergic skin } \\
\text { disease }\end{array}$ & $\begin{array}{l}\text { Main work task in relation with } \\
\text { disease }\end{array}$ & $\begin{array}{l}\text { Concluded as } \\
\text { occupational } \\
\text { disease }(\mathrm{Y} / \mathrm{N})\end{array}$ \\
\hline \multicolumn{6}{|l|}{ Live animals: 10 patients ( $28.6 \%)$} \\
\hline Pig farmer & 25 & Additives in food of pigs & Allergic contact eczema & Feeding & Yes \\
\hline Technician in pig farming & 27 & Glutaraldehyde & Allergic contact eczema & Cleaning, Disinfection & Yes \\
\hline Pig farmer & 36 & Formaldehyde, benzalkonium chloride & Allergic contact eczema & Cleaning, Disinfection & Yes \\
\hline Poultry farming employee & 38 & Glutaraldehyde & Allergic contact eczema & Cleaning, Disinfection & Yes \\
\hline $\begin{array}{l}\text { Poultry farming employee for } \\
\text { maintenance }\end{array}$ & 55 & Glutaraldehyde & Allergic contact eczema & Cleaning, Disinfection & Yes \\
\hline Milk productor & 50 & PPD (paraphenylenediamine) & Allergic contact eczema & Milking & Yes \\
\hline Milk productor & 40 & Sorbic acid & Allergic contact eczema & Feeding & Yes \\
\hline Milk productor & 37 & Nickel & Allergic contact eczema & Milking & No \\
\hline Cattle farmer & 24 & Cattle dander & Protein contact dermatitis & Milking, animal feeding & Yes \\
\hline Rabbit farmer & 48 & Grasses proteins & Protein contact dermatitis & Feeding & Yes \\
\hline \multicolumn{6}{|c|}{ Fruit and vegetables farming: 7 patients $(20.0 \%)$} \\
\hline Agricultural employee & 58 & Nickel, cobalt & Allergic contact eczema & Sorting shallot and potatoes & Yes \\
\hline Tomato greenhouse worker & 58 & $\begin{array}{l}\text { Lactones, benzalkonium chloride, } \\
\text { glutaraldehyde, vinyl gloves }\end{array}$ & Allergic contact eczema & Cleaning & Yes \\
\hline Tomato greenhouse worker & 31 & Tomato proteins, celery, peanut & Protein contact dermatitis & Picking, sorting, cleaning & Yes \\
\hline Tomato greenhouse worker & 27 & Tomato proteins & Protein contact dermatitis & Picking, sorting, Cleaning & Yes \\
\hline Manager farmer & 51 & Shiitake proteins & Protein contact dermatitis & Picking, sorting, cleaning & Yes \\
\hline Parsley market garden worker & 53 & Parsley and latex proteins & Protein contact dermatitis & Picking, sorting, cleaning & Yes \\
\hline Seasonal agricultural worker & 36 & Artichoke proteins & Protein contact dermatitis & Picking, sorting, cleaning & Yes \\
\hline \multicolumn{6}{|l|}{ Non-food flora: 3 patients $(8.6 \%)$} \\
\hline Horticulture worker & 41 & Pesticide & Allergic contact eczema & Chemical treatment of plants & Yes \\
\hline Horticulture seasonal worker & 46 & Alstromeria & Allergic contact eczema & Repotting & Yes \\
\hline \multicolumn{6}{|c|}{ Industrial packaging sector: 10 patients $(28.6 \%)$} \\
\hline Packer in agri-food processing plants & 24 & Professional soap, lanoline & Allergic contact eczema & Cleaning & Yes \\
\hline Packer in agri-food processing plants & 41 & Cleaning and disinfection product & Allergic contact eczema & Cleaning & Yes \\
\hline Packer in agri-food processing plants & 51 & $\begin{array}{l}\text { Isothiazolinone } \\
\text { Professional soap }\end{array}$ & Allergic contact eczema & Cleaning & Yes \\
\hline Packer in agri-food processing plants & 40 & Quaternium 15 & Allergic contact eczema & Cleaning & Yes \\
\hline $\begin{array}{l}\text { Cleaning operative in agri-food } \\
\text { processing plants }\end{array}$ & 39 & Disperse blue (working boots) & Allergic contact eczema & Cleaning & Yes \\
\hline $\begin{array}{l}\text { Cleaning operative in agri-food } \\
\text { processing plants }\end{array}$ & 29 & Thiuram mix (rubber) & Allergic contact eczema & Cleaning & Yes \\
\hline Maintenance technician & 61 & $\begin{array}{l}\text { Penngar DTUÒ and Topax } 9900 \\
\text { (Disinfection products) }\end{array}$ & Allergic contact eczema & Disinfection & Yes \\
\hline Maintenance technician & 36 & Poultry proteins & Protein contact dermatitis & Cleaning & Yes \\
\hline Meat cutter & 33 & Pig proteins & Protein contact dermatitis & Meat cutting & Yes \\
\hline Meat cutter & 26 & Pig, cattle, sheep proteins & Protein contact dermatitis & Meat cutting & Yes \\
\hline \multicolumn{6}{|l|}{ Other: 5 patients ( $14.2 \%$ ) } \\
\hline Technician & 40 & Sodium metabisulfite & Allergic contact eczema & Preservative used in mixed food & Yes \\
\hline Agricultural equipment driver & 34 & Isothiazolinone & Allergic contact eczema & Maintenance, contact with oils & Yes \\
\hline Stand-in farmer & 56 & Epoxyde & Allergic contact eczema & - & No \\
\hline Farmer & 17 & Non-identified & Allergic contact eczema & - & No \\
\hline Farmer & 22 & Fragrance in a detergent & Allergic contact eczema & Cleaning & Yes \\
\hline
\end{tabular}


picker where the irritant was contact with the artichokes. Four cases were determined in the non-food flora group who were 4 parks and gardens maintenance workers, the irritants were their protective oilskins. Two cases were diagnosed in the industrial packaging sector group:1 packer in the agrifood industry, without identification of the irritant, and 1 cleaning operative in the agri-food industry where the irritant was sodium hypochlorite.

\section{Focus on the 5 patients with infectious skin disease.}

Gender. There were 3 male patients and 2 female patients. The gender ratio was therefore 1:5. There was no significant difference with the other patients in the study.

Age. This subgroup comprised patients aged 29 - 48 years; median - 39 years; mean - 37 years. There was no significant difference in the age of patients with irritant contact dermatitis compared with other patients in the study.

Occupational etiology. There was only 1 case of occupational infectious skin disease (mycosis).

Other infectious skin diseases determined as nonoccupational. One case was found in the live animals group, i.e. 1 dairy farmer with skin and nail mycosis of the feet (B48.8 Trichophyton Rubrum), which was long-standing but could be exacerbated by the work environment. Two cases were revealed in the non-food flora group, i.e. 1 technical services worker in the council's parks and gardens department with ringworm (B35.2), and 1 landscape gardener with scabies (B86). Two cases were diagnosed in the industrial packaging sector group, i.e. 1 agri-food worker with a parvovirus B19 (B33.8), and 1 grain processing worker with folliculitis (L08).

\section{DISCUSSION}

This study has provided a detailed account of a target population of individuals attending the Occupational Dermatology Clinic at Brest University Hospital in Brittany. One major strength of the study was the fact that the diagnoses were always discussed by a multi-disciplinary team. According to France's National Institute of Statistics and Economic Studies, the study population should have represented between $7.4 \%-11.5 \%$ of all consultations at the clinic, based on Brittany's epidemiology ( $4 \%$ of agricultural workers $+40 \% \times 13.7 \%$ of industrial workers). Hence, the studied population, representing $10.7 \%$ of the total number of patients, did not seem to be over-represented at the Occupational Dermatology Clinic.

There was a higher representation of male than female patients in the studied population, but given the sociodemographic data of the agricultural sector, this gender ratio is not surprising [6]. Nevertheless, there was a significant gender ratio difference between the population who participated in the current study, and the rest of the patients attending the clinic $(\mathrm{p}<0.0052)$. This difference can be explained by the fact that a substantial number of patients attending the clinic came from the highly feminised paramedical professions (nurses, midwives, health care assistants, hospital cleaners), which would explain the overall gender ratio at the clinic of 1.3 [4].
The age of patients attending the clinic also corresponded with expected values. The legal employment age in France is 16 - 65 years, although it is legally possible to employ workers under the age of 16 under certain conditions (Article L4153-1 of the Labour Code sets out the provisions specific to certain categories of workers). That said, patients can also benefit from post-occupational medical monitoring with no legal time limit (Article D461-25 of the Social Security Code sets out the provisions concerning occupational diseases). Ultimately, all the patients attending the clinic were still professionally active. There were no retirees, unlike in other populations.

The most common types of occupational skin disease in the examined population were found to be allergic contact dermatitis and irritant contact dermatitis. These results were broadly comparable with the national data on the main non-cancerous skin-surface affections indemnified in 2000 in France $[4,11]$, which included $76.3 \%$ cases of allergic contact dermatitis and $14.6 \%$ of irritant dermatitis and other studies in these professional sectors [7-9]. However, the file coding in the RNV3P presented some biases, including a probable underestimation of the actual prevalence of irritant dermatitis mostly when compared with self-reported skin diseases $[8,10]$.

With regard to the main diagnosis in the coded dermatitis, allergic contact dermatitis was always presented first over irritant dermatitis. In fact, when the 2 types were combined, allergic contact dermatitis always came out on top again in the diagnostic summary, totally dominating irritant dermatitis. There were therefore certainly many more cases of irritant contact dermatitis in the studied population than the number suggested indicated by the file coding.

With regard to the allergens found in this study, biocides were often identified (13 of 35 cases [37\%]). Benzalkonium chloride, which is used for its disinfectant properties, is a well-known irritant $[12,13]$, but it was also found to be a source of allergies in the agricultural sector in the study and is usually described in connection with the care environment [2]. The other allergens identified in cleaning and disinfection products were glutar aldehyde, isothiazolinone, quaternary ammonium compounds and formaldehyde. Metabisulfite, a food preservative, was also found. This is a quite frequent allergen among the general population, but there have also been cases of occupational sensitisation described for the agri-industrial sector [14]. Nickel was found in 2 cases, and epoxides, latex and rubber were each identified once.

Plant allergens included shiitake mushrooms, which are better known for their respiratory than their cutaneous effects [15], artichokes, tomatoes, grasses, parsley, celery and alstromeria.

In terms of animal proteins, allergies were found to pig, cow and chicken proteins.

Previous studies have found some of these allergens in cases of occupational allergic contact dermatitis:

- in France from 1996-2000, among 200 patients: metals, antiseptics and preservatives, rubber vulcanising agents, latex and hair products [16];

- in the USA from 1998-2000 among 1,097 patients: rubber vulcanisation accelerators, nickel, formaldehyde and epoxy resins [17];

- in Denmark from 2001-2002 among 758 patients: chromium, nickel and rubber [18]; 
- in the United Kingdom from 1996 - 2015 among 1,776 patients: $4.2 \%$ had occupational allergic contact dermatitis that was attributable to fragrances, compared with $2 \%$ of the general population [19].

The number of patients included in each subgroup of the current study was relatively small, which prevented a conclusion on any potential significant overrepresentation of one particular work environment. It would seem there was a higher prevalence of representatives from the dairy, tomato growing, pig farming [20], parks and gardens maintenance, and agri-food industry sectors attending this multidisciplinary clinic, which is consistent with the proportion of this type of employment in Brittany.

There was little representation at the clinic by cauliflower farm workers (only 1 case), and no representation at all from spinach and shallot farm workers. This was surprising given the size of this economic sector. It is therefore possible that the hospital clinic tended only to see severe cases, and that contact dermatitis caused by spinach, shallots and cauliflower was well managed by private community-based health services and did not require occupational dermatology advice.

Workers exposed to Brittany's terrestrial fauna and flora are at risk of contracting many specific infectious diseases which can present cutaneous manifestations. It was therefore expected that diagnoses of pasteurellosis, leptospirosis, tularemia, cutaneous tuberculosis, erysipeloid of BakerRosenbach, mycoses, brucellosis, Lyme disease, onyxis and peri-onyxis would be found at the clinic. However, only 1 such occupational infectious skin disease was found - mycosis.

The 'healthy worker effect' cannot be ruled out in this study. The morbidity and mortality rate is lower in a population of workers than in the general population due to the fact that an individual must be in relatively good health to be employable, and that a disabling condition may exclude them from the labour market [21]. The diseases found at the clinic were generally either atypical, or they were more serious than the average case because less complex cases of dermatitis were being managed by general practitioners or through selfmedication, owing to the fact they can sometimes be treated empirically with no diagnosis of an occupational disease being made. It is also likely that, given the consultation time frame (approximately 1 month), there would have been no cases of acute attacks, which could potentially partly explain the low presence of infectious skin diseases at the clinic. In addition, some infectious diseases (systemic) may have been referred directly to infectiology, pneumology, general medicine, etc.

Given that the presented study was monocentric, it cannot be considered exhaustive or representative of the whole of France. Because data collection was retrospective, it was not possible to clarify a number of elements in the files, including notably details about the patients' work environments and the precise identification of certain harmful substances and supplementary tests. In addition, it would appear that the primary sector allergens were usually derived from living organisms, while the secondary sector allergens were linked to cleaning products (i.e. manufactured chemical products) [22]. It would therefore be interesting to extend the study by carrying out a prospective follow-up investigation over several years of a representative population of workers exposed to Brittany's fauna and flora in order to give a clear picture of the proportion of these dermatological diseases among these specific workers.

In the case of contact dermatitis, sources of exposure must be avoided, and cutaneous toxins should be replaced by xenobiotics that cause little or no harm to the skin surface. Where replacement is not possible, it is essential that gloves are worn to protect the skin (polymers are preferred over leather or latex in this specific environment). The removal of an individual from the work environment should only really be considered as a second step. The organic allergens found in this study had often resulted from the production process. Replacing them could therefore potentially affect the entire production process. However, the other frequent source of allergens - cleaning products, is easily replaceable, particularly by fragrance-free products which are often better tolerated.

\section{CONCLUSIONS}

At the Occupational Dermatology Clinic at Brest University Hospital, cases of occupational contact dermatitis were mainly found, as opposed to infectious skin diseases, in workers exposed to Brittany's terrestrial fauna and flora.

The most frequent professional groups presenting with occupational dermatitis at the clinic were the industrial packaging, cattle farming (especially dairy), tomato growing, pig farming and parks and gardens maintenance sectors. As such, they should be offered targeted preventive action as a priority.

Overall, there did not seem to be a major risk of occupational skin diseases among workers exposed to Brittany's terrestrial fauna and flora in this population, compared with other professional sectors, such as hairdressing or care work. In fact, in this specific working population of Brittany, the incidence rate of annual occupational skin diseases cases (diagnosed at the Brest University Hospital Clinic) have been assessed as $3-5$ per 100,000 workers.

Ultimately, further studies are needed for a more comprehensive approach to skin diseases in a population working in an agricultural environment.

\section{REFERENCES}

1. Lachapelle JM, Frimat P, Tennstedt D, Ducombs G. Précis de dermatologie professionnelle et de l'environnement. Paris: Masson, 1992: 1-400.

2. Crepy MN, Rosenberg N. Allergies en milieu professionnel, Dossier INRS, 2005: 1-12

3. Loddé B, Roguedas AM. Dermatoses professionnelles. EMCDermatologie 2014; 9: 1-14.

4. Garçon-Michel N, Paul M, Loddé B, Roguedas-Contios AM, Misery L. Consultation spécialisée de dermatologie professionnelle: bilan de cinq ans d'activité. Place de l'atopie. Annales de Dermatologie et de Vénéréologie 2010; 11: 681-7.

5. Mathias CG.Contact dermatitis and workers' compensation: criteria for establishing occupational causation and aggravation. J Am Acad Dermatol. 1989 May; 20(5 Pt 1): 842-8.

6. Potin F, Dubois M. Recencement agricole 2010. Agreste Bretagne2011.

7. Spiewak R. Farmers and farm workers. In: John SM, Johansen JD, Rustemeyer T, Elsner P, Maibach H, editors. Kanerva's Occupational Dermatology. Cham: Springer; 2018.

8. Susitaival P, Husman L, Hollmen A, Horsmanheimo M. Dermatoses determined in a population of farmers in a questionnaire-based clinical study including methodology validation. Scand J Work Environ Health. 1995; 21(1): 30-5. 
9. Spiewak R, Gora-Florek A, Horoch A, Jarosz M, Dorynska A, Golec $\mathrm{M}$, et al. Risk factors for work-related eczema and urticaria among vocational students of agriculture. Ann Agric Environ Med. 2017; 24(4): 716-21.

10. Susitaival P, Beckman R, Samuels SJ, Schenker MB. Self-reported dermatitis and skin cancer in California farm operators. Am J Ind Med. 2004; 46(2): 136-41.

11. Caisse Nationale de l'Assurance Maladie des Travailleurs Salariés. Principales pathologies non cancéreuses du revêtement cutané indemnisées en 2000, statistiques financières et technologiques des accidents de travail, Années 1998-1999-2000. Paris, 2002: 1-410.

12. Paul M, Loddé B, Roguedas-Contios AM, Eniafe-Eveillard MB Misery L, Dewitte JD. Dermatoses professionnelles induites par les désinfectants, détergents et antiseptiques. A propos de 50 patients d'une consultation de dermatologie professionnelle. Archives des Maladies professionnelles et de l'environnement, 2009.

13. Corazza M, VIRGILI A. Airborne allergic contact dermatitis from benzalkonium chloride. Contact dermatitis 1993; 28: 195-6.

14. MadanV, Walker SL, BECK MH. Sodium metabisulfite allergy is common but is it relevant? Contact Dermatitis 2007; 57: 173-6.
15. Ueda A, Obamai K, Aoyama K, Ueda T, Xul BH, LI Q, Huang J, Kitand $\mathrm{T}$, lnaoka T. Allergic contact dermatitis in shiitake (Lentinus edodes (Berk) Sing) growers. Contact Dermatitis 1992; 26: 228-33.

16. Crépy MN, Bensefa L, Lauzier F, et al. Dermatoses professionnelles. Journées de l'institut interuniversitaire de médecine du travail de Paris Ile de France, Paris 15 March 2006. Document pour le médecin du Travail 2006; 106: 217-23.

17. Rietschel RL, Mathias CG, Fowler Jr JF, Pratt M, et al. Relationship of occupation to contact dermatitis: evaluation in patients tested from 1998 to 2000. Am J Contact Dermat. 2002; 13: 170-6.

18. Skoet R, Olsen J, Mathiesen B, Iversen L, et al. A survey of occupational hand eczema in Denmark. Contact Dermatitis. 2004; 51: 159-66.

19. Montgomery RL, Agius R, Wilkinson S, Carder M. UK trends of allergic occupational skin disease attributed to fragrances 1996-2015. Contact Dermatitis. 2017; 78: 33-40.

20. Spiewak R. Occupational dermatoses among Polish private farmers, 1991-1999. Am J Ind Med. 2003; 43(6): 647-55.

21. Li CY, Sung EC. A review of the healthy worker effect in occupational epidemiology. Occup Med. 1999; 49: 225-9.

22. Bédague P, Pelé A, Clappier P, Valenty M. Surveillance des maladies à caractère professionnel, résultat des quinzaines 2013 en région Bretagne, Les maladies à caractère professionnel 2014; 2 . 